\title{
OBAT PENAWAR DAN PENYAKIT DI SAYAP LALAT (INTEGRASI-INTERKONEKTIF HADIS DENGAN ILMU PENGETAHUAN)
}

\author{
Muhammad Patri Arifin \\ Institut Agama Islam Negeri (IAIN) Palu \\ Email: muhammadpatriar@gmail.com
}

\begin{abstract}
This article is a library research which aims to reveal the interconnectivity of hadith with science, with the hadith about flies as a case in point. At least, there are 4 patterns of relationship between religion and science, namely conflict, independence, dialogue, or integration. Without reflecting on these 4 patterns, the principle of understanding religion will not be possible to do perfectly, because it is separate from the reality of human life. By using thematic methods and historical-sociological approaches to these hadiths, this article arrives at the findings that most of the microorganisms such as germs, viruses and microbes that are present in the body of flies can cause a number of diseases, but the micro development of living things on the fluids they inhabit can neutralized by submerging it. This proves that the discovery of science is in harmony and synergy with the hadith of the Prophet.
\end{abstract}

Key Words: Flies, Integration-Interconnectivity, Science

\begin{abstract}
Abstrak
Artikel ini merupakan riset kepustakaan (library research) yang bertujuan mengungkap integrasi-interkonektif hadis dengan ilmu pengetahuan, dengan hadis tentang lalat sebagai contoh kasusnya. Setidaknya, ada 4 pola hubungan antara agama dan ilmu pengetahuan, yaitu Konflik, Independensi, Dialog, atau Integrasi. Tanpa merefleksikan 4 pola tersebut, maka prinsip pemahaman agama tidak akan mungkin dilakukan dengan sempurna, karena
\end{abstract}


terpisah dari kenyataan hidup manusia. Dengan menggunakan metode tematik dan pendekatan historis-sosiologis terhadap hadis tersebut, artikel ini sampai pada temuan bahwa sebagian besar mikro makhluk hidup seperti kuman, virus dan mikroba yang terdapat dalam tubuh lalat dapat menyebabkan sejumlah penyakit, namun perkembangan mikro makhluk hidup terhadap cairan yang dihinggapinya dapat dinetralisir dengan cara menenggelamkannya. Hal ini membuktikan penemuan ilmu pengetahuan memiliki keserasian dan sinergitas dengan hadis Nabi.

Kata Kunci: Lalat, Integrasi-Interkonektif, Ilmu Pengetahuan.

\section{Pendahuluan}

Ketika Alquran dinobatkan sebagai mukjizat terbesar Nabi Muhammad diantaranya dikarenakan muatan isinya banyak mengandung pernyataan-pernyataan yang sangat menakjubkan berkenaan dengan fenomena Alam, seperti penciptaaan langit dan bumi dari keterpaduan, matahari dan bulan beredar dalam orbitnya, air sebagai sumber dari semua makhluk hidup, perkembangan janin dalam kandungan yang sangat detail dan akurat. Maka posisi Nabi Muhammad dan segala cacatan tentang kehidupannya yang tertuang dalam Hadis pun berpotensi untuk menjadi hal yang bermukjizat. Mukjizat tentu saja menggambarkan keadaan yang luar biasa, selain berfungsi unutk melemahkan argument orangorang yang tidak percaya kepada seseorang yang memilikinya, juga berfungsi untuk menunjukkan bahwa apa yang dibawa oleh sang pemilik mukjizat adalah kebenaran yang diperoleh dari Sang kebenaran. ${ }^{1}$ Kebenaran itu dapat terlihat dari argument-argumen yang dilontarkan sejak beberapa abad yang lalu, dan baru bisa dibuktikan validitas argument tersebut pada periode terbaru

${ }^{1}$ Zaghlul an Najjar, al Ijaz al Ilmy fi As Sunnah An Nabawiyah, diterjemahkan oleh Zainal Abidin (Jakarta: Sinar Grafika, 2011), h. xvii 
perjalanan manusia melalui penemuan-penemua ilmiah modern. Penemuan-penemuan ilmiah modern ini selain telah membantu umat Islam untuk memahami maksud yang tersembunyi dari muatan isi Alqurandan hadis, juga dapat dijadikan sebagai media dakwah untuk meyakinkan kepada seluruh umat manusia yang di dalam hatinya terdapat keraguan terhadap kebenaran-kebenaran agama, khususnya bagi orang yang meragukan kedudukan hadis Nabi sebagai sumber kedua ajaran Islam, meski diakui bahwa ada beberapa hadis yang tidak dapat digunakan sebagai hujjah (pegangan) bagi sebagian ulama karena beberapa pertimbangan mendasar, seperti, kualitas hadis hanya terbatas pada kategori hadis ahad, cakupan hadis bukan pada wilayah syariat agama tetapi tentang kehidupan duniawi dan bertolak belakangnnya dengan akal sehat manusia dan realitas.

\section{Persepsi Terhadap Hadis}

Apakah semua yang diberi label Hadis otomatis dijadikan pegangan (agama) oleh ulama? Belum tentu. Hadis mutawatir karena tidak diragukan otentisitasnya ia bisa secara langsung dijadikan dalil agama, tetapi para ulama meskipun mempergunakan dalil yang sama, tetapi hasil pengamalannya belum tentu sama karena metode interpretasinya tidak sama. Untuk hadis ahad, para ulama sangat perlu mempertimbangkan terlebih dahulu, sahih apa tidak $^{2}$. Hadis sahih sendiri masi ada cela untuk diperdebatkan, karena bisa jadi suatu hadis memang dari segi sanad telah dinyatakan sahih, tapi dari segi matan mungkin sangat berat untuk dikatakan sahih karena beberapa alasan ${ }^{3}$ untuk tidak

\footnotetext{
${ }^{2}$ Muh. Zuhri, Telaah Matan Hadis: Sebuah Tawaran Metodologis, (Yogyakarta: Lesfi, 2003) h. 28

${ }^{3}$ Ada beberapa alasan, diantaranya: tidak bertentangan dengan al Quran dan Hadis yang lebih kuat, tidak bertentangan dengan ajaran pokok Islam dan ketatapan sunnatullah, dan tidak bertentangan dengan fakta sejarah dan akal sehat. Lihat Suryadi, Metode Penelitian Hadis, (Yogyakarta: Teras, 2009) h. 146.
} 
mensahihkannnya. Oleh karena itu, selain perlunya kritik eksternal (sanad) dari satu hadis, juga kritik internal (matan) sangat menentukan untuk mensahihkan satu hadis. ${ }^{4}$

Salah satu hadis nabi yang masih menjadi perdebatan ulama adalah hadis tentang 'lalat yang hinggap pada satu minuman hendakanya ditenggelamkan', apakah bisa dijadikan pegangan atau tidak. Bagi penolak hadis ini berkesimpulan bahwa hadis ini berada pada ranah kehidupan manusiawi, dan sangat bertentangan dengan realitas dan sulit diterima oleh akal, sehingga mereka mengkritisinya tanpa harus terbebani dengan rasa salah atau berdosa. ${ }^{5}$ Sebagaimana pandangan umum, lalat itu hewan pembawa penyakit yang harus disingkiri, bahkan diberantas. Betapa banyak orang terserang penyakit karena menkonsumsi makanan yang dihinggapi lalat. Alasan yang serupa juga diolontarkan oleh Abu Rayyah bahwa hadis tentang lalat ini sangat bertentangan dengan realitas penelitian para ilmuwan yang menetapkan lalat adalah salah satu sumber yang bisa mendatangkan kemudaratan dan penyakit, terlebih hadis yang menyinggungnya berada pada wilayah urusan duniawi, dimana pada diri Nabi sendiri terdapat contoh yang jelas ketika dihadapkan pada keterangan yang disandarkan padanya tentang hal yang bersifat duniawi, beliau pernah mengatakan kepada para sahabatnya, 'kalian lebih mengetahui urusan dunia kalian masing-masing' ${ }^{6}$

Lihat juga al Adhlabi, Manhaj al-Naqd Inda al-Muhaddithïn. (Beirut: Dar alHadits, 2002), h. 240.yang diterjemahkan oleh Ita Qonita dengan judul Menalar Sabda Nabi, (Yogyakarta: Insan Madani, 2010) h. 284.

${ }^{4}$ Abu Rayyah, Adwa' ala as Sunnah al-Nabawiyyah, (Mesir: Multazam Press, 1985) h. 200, lihat juga Nurun Najwah, Pemahaman Kontekstual HadisHadis Reproduksi Manusia, (Yogyakarta: TH Press, 2008) h. 10

${ }^{5}$ Muh. Zuhri, Telaah Matan Hadis: Sebuah Tawaran Metodologis, (Yogyakarta: Lesfi, 2003) h.78

${ }^{6} \mathrm{Abu}$ Rayyah, Adwa' ala as Sunnah al-Nabawiyyah, (Mesir: Multazam Press, 1985) h. 201. 
Memang tidak dapat diragukan bahwa lalat membawa kuman yang mampu membunuh. Lalat menularkan kuman itu di segala sesuatu yang ia hinggapi, baik makanan, minuman maupun barang-barang lain. Hadis ini secara jelas menetapkan bahwa pada salah satu sayapnya terdapat penyakit. Tetapi masalahnya adalah, jikalau para pengritik hadis ini menemukan hal yang bertentangan dengan akal sehat sehingga mereka berkesimpulan unutk tidak mempergunakannya, namun pada penelitian ilmuwan yang paling terakhir, justru telah mangakui akan kebenaran keterangan hadis Nabi ini, bahwa pada salah satu dari sayapnya terdapat obat penawar dari berbagai penyakit yang mungkin saja bisa dimunculkan. Maka pada posisi inilah, bagi para pembela hadis menanggapi secara wajar dari penolakan yang telah ada, bahwa jangan sampai hanya karena belum diteliti secara benar hadis ini segera ditolak, terlebih sanad hadisnya termasuk hadis yang sahih.

Jikalau perdebatan muatan isi hadis ini dibawah dalam ranah penelitian ilmiah yang dikenal dengan (grounded research ${ }^{7}$ ), maka teori yang pertama kali muncul bahwa lalat adalah biang dan sumber penyakit sehingga konsekuensi dari kesimpulan ini hadis Nabi mesti ditolak, sedangkan pada penelitian lebih lanjut, ternyata menghasilkan kesimpulan bahwa pada salah satu sayap terdapat obat penawar, maka hadis ini harus diterima karena telah terbukti kebenarannya secara ilmiah. Meskipun seandainya hadis ini memiliki kekuatan riwayat yang lemah, tetapi karena kesesuaian isi

${ }^{7}$ Grounded research adalah metode penelitian social yang bertujuan untuk menemukan teori melalui data-data yang diperoleh secara sistematik dengan menggunakan metode analisis komparatif konstan. Dalam metode ini, beberapa hipotesis mungkin jatuh bangun selama penelitian lapangan berlangsung, dan hipotesis yang tetap tegak, yang ditopang oleh data akhir dari lapangan penelitian itulah yang akan menjadi hasil dari penelitian dan sekaligus menjadi teori hasil penelitian. Lihat Ato Muddzhar, Pendekatan Studi Islam dalam Teori dan Praktik, (Yogyakarta: Pustaka Pelajar, 2004), h. 46-47 
matan hadis dengan pembuktian ilmiah dapat menguatkan keotentikan hadis serta dapat dijadikan pegangan beragama.

Namun perlu ditekankan bahwa apa yang ditemukan oleh para ilmuwan modern tentang teori ilmu pengetahuan, tidak serta merta bisa langsung dianggap sebagai ketetapan dan hakikat yang bersifat final. Sebagaimana yang dikemukakan oleh Sayyid Kutub bahwa dalam mengkaji al Quran, seorang tidak harus merujuk kepada hipotesa-hipotesa yang selama ini dianggap sebagai kebenaran paling final, karena hipotesa itu hanya sekedar sekumpulan teori yang setiap saat bisa berubah dan dibenahi. Sementra itu, dalam kasus keterangan yang ada dalam Alqurantidak dapat diperlakukan sebagaimana perlakuan terhadap teori ilmuwan.

\section{Validitas dan Ulasan Hadis}

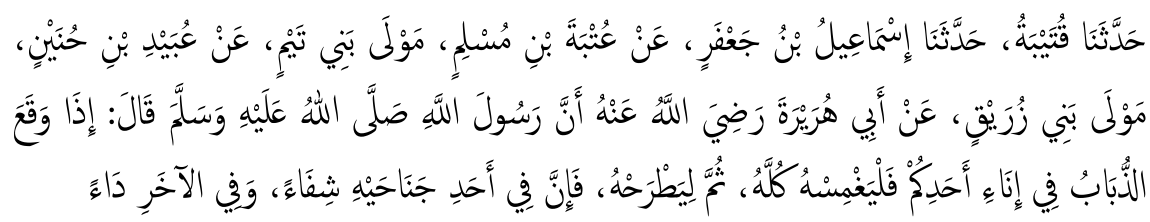

Artinya: "Jika lalat hinggap ke minuman salah seorang diantara kalian, maka hendaklah ia menenggelamkannya, kemudian buanglah (lalat tersebut), karena sesungguhnya di salah satu sayapnya ada penyakit, dan di sayap lainnya ada obat."

Hadis diatas telah diriwayatkan oleh beberapa ulama hadis dalam berbagai kitab hadis yang ada, diantaranya ${ }^{8}$ : Diriwayatkan oleh Imam Bukhari dari Abu Hurairah (Sahih Bukhari: 3320, 5782), Imam an Nasai dari Abu Said al Khudri (Sunan an Nasai: 4189), Imam Abu Daud dalam kitab sunannya dari Abu Hurairah (Sunan Abu Daud: 3346), Imam Ibn Majah dari Abu Said al Khudri (Sunan Ibn Majah: 3459), Imam Ahamd bin Hanbal dalam Musnadnya dari

\footnotetext{
${ }^{8}$ Zaglul an Najjar, al Ijaz al Ilmy fi As Sunnah An Nabawiyah, h. 277
} 
Abu Hurairah (Musnad: 6844), Imam Ad Darimy dari Abu Hurairah (Sunan Ad Darimy: 1951) Dan terakhir, hadis ini diriwayatkan juga oleh para Imam hadis selain diatas seperti, Imam Al Baihaqi, Ibn Hibban dan Ibn Khuzaemah. Dari keterangan ini juga, membatalkan tuduhan dari Abu Rayyah bahwa hadis ini hanya diriwayatkan oleh Abu Hurairah.

Adapun maksud dari hadis ini adalah perintah untuk menjaga minuman dari jangkauan hal-hal yang dapat mencemari sehingga dapat menimbulkan bahaya bagi yang akan meminumnya. Namun, jika terpaksa minuman tersebut harus terhinggapi oleh lalat yang notabene adalah hewan yang sudah pasti membawa bakteri, maka Nabi memberitahukan bahwa pada salah satu sayap lalat terdapat penyakit dan pada sayap yang lain terdapat obat penawar untuk penyakit tersebut. ${ }^{9}$

Sebagian orang keberatan terhadap kemungkinan dicelupkannya lalat ke dalam makanan atau minuman yang kemasukan lalat, untuk kemudian memakan kemabali makan tersebut. Namun, keberatan mereka kurang tepat, mereka lupa bahwa hal tersebut dilakukan jika dalam keadaan yang sangat darurat, misalnya ketika seseorang berada ditengah padang pasir dan tidak memiliki apapun kecuali segelas air atau segelas minuman yang telah kemasukan lalat itu, sedang dia khawatir akan meninggal dunia jika tidak mengkonsumsi minuman ini, sehingga dia harus menolak dua bahaya sekaligus: bahaya kematian karena lapar dan dahaga atau bahaya kematian karena kuman, bakteri dan virus yang dibawa lalat dalam minumannya.

Oleh karena itu, demi untuk menghindari penyia-nyiaan air karena disangka air telah tercemari kuman yang dibawah oleh lalat,

${ }^{9}$ Shalih Fauzan, Tashil al Ilmam bi Fiqh al Ahadis min Bulug al Maram (Beirut: Dar al-Hadits, 2001), h. 60 
apalagi air tersebut merupakan barang yang sangat dibutuhkan, sebaiknya ditenggelamkan saja lalat tersebut kedalam minuman, karena ketika lalat terjatuh dalam makanan atau minuman, dia akan otomatis mengepakkan sayapnya yang mengadung obat penawar, dan unsur-unsur obat akan menyerang unsur penyakit dengan izin Allah. Artinya, penyakit yang dibawa oleh lalat, dapat teratasi dengan adanya penawar penyakit tersebut yang berada pada salah satu sayapnya. Beberapa ulama mengatakan bahwa bakteri atau penyakit berada pada sayap yang sebelah kiri, dan sayap kanannya sebagai penawar. ${ }^{10}$

Orang yang masih keberatan dan tidak menerima kemungkiana meminum minuman yang sudah terceburi lalat, sedangkan dia sendiri belum pernah mengalami keadaan daruruat yang memaksanya melakukan hal ini, maka dia tidak bisa meragukan kesahihan hadis ini begitu saja hanya karena tidak dapat menerima minuman yang telah tercampur lalat yang identik dengan kotoran dan pembawa penyakit. ${ }^{11}$ Hal yang senada juga dikemukakan oleh Yusud Qardhawi bahwa hadis ini berisi anjuran dalam hal persoalan duniawi, khususnya dalam kondisi krisis ekonomi dalam lingkungan tertentu yang mengalami kekurangan bahan pangan, agar tidak membuang makanan yang telah terhinggapi lalat, bahkan hadis ini memberikan penekanan tentang pembinaan generasi untuk hidup sederhana dan bersikap tidak boros. $^{12}$

\footnotetext{
${ }^{10}$ Ibn Hajar al Asqalani, Fath Bari (Beirut: Dar al Ma'rifah, 1379 H), juz X, h. 251

${ }^{11}$ Zaghlul an Najjar, al Ijaz al Ilmy fi As Sunnah An Nabawiyah, h. 279

${ }^{12}$ Yusuf Qardawi, Kaifa Nata’amal maa al Sunnah al Nabawiyah, diterjemahkan oleh Muhammad al Baqir dengan judul Bagaimana memahami Hadis Nabi, (Bandung: Kharisma, 1994), h. 23.
} 
Didalam Fathul Bari Syarah Shahih Bukhari dijelaskan bahwa ketahuilah bahwa pada lalat terdapat racun (kuman penyakit) yang terletak pada sengatnya yang merupakan senjata bagi dirinya. Jika ia jatuh atau hinggap pada sesuatu, maka yang pertama menyentuh adalah senjata tadi. Oleh sebab itulah Nabi Muhammad memerintahkan agar mencelupkan lalat itu ke dalam makanan atau minuman yang dihinggapinya. Tujuannya agar kuman penyakit itu menjadi tawar (tidak berfungsi lagi) dan hilanglah dengan izin Allah bahaya yang ditimbulkannya akibat pertemuan dengan salah satu sayap lainnya yang mengandung penawar dari racun tersebut. ${ }^{13}$

Sedangakan menurut Ibn Qayyim, hadis ini mengandung dua aspek yaitu aspek fiqih dan aspek kesehatan. Mengenai aspek fiqih, hadis tersebut menyatakan bahwa seekor lalat yang jatuh di dalam air atau cairan tidak menjadikan air atau cairan itu tidak suci. ketentuan ini berlaku secara umum pada jenis serangga seperti lebah, laba-laba. Sedangkan hewan lainnya yang mati dikatakan tidak suci karena darahnya tetap terperangkat dalam tubuh, berbeda dengan serangga yang tidak memiliki darah. Dalam kasus ini, Ibnu Hajar menyebutkan hadis tentang lalat ini dalam kitab bulug al maram pada bab tentang air. Adapun yang berkenaan dengan nilai medis, karena lalat mengandung materi-materi racun yang menjadi senjata pertahanan serangga itu maka untuk menetralisir zat-zat racun yang dihasilkan maka Allah menyediakan penawarnya pada salah satu sayapnya. ${ }^{14}$

${ }^{13} \mathrm{CD}$ Mausuah Maktabah Syamilah, Ibn Hajar, Syarah Fathul bari, Jilid 10, h. 252

${ }^{14}$ Ibn Qayyim al Jauziyah, at Tibbun an Nabawy, terjemahan oleh Abu Firly (Yogyakarta: Hikam Pustaka, 2010), h. 150 


\section{Integrasi-Interkonektif Hadis dengan Ilmu Pengetahuan}

Sebagaimana dipaparkan oleh Ian G. Barbour, setidaknya, ada 4 pola hubungan antara agama dan ilmu pengetahuan, yaitu Konflik (bertentangan), Independensi (masing-masing berdiri sendiri-sendiri), Dialog (berkomunikasi) atau Integrasi (menyatu dan bersinergi). ${ }^{15}$ Ketika ilmu agama masih mengandalkan independensinya atau lebih mengedepankan pertentangannya dengan realitas perkembangan ilmu pengetahaun dan teknologi, tanpa melakukan dialog atau melakukan pensinergian sedikitpun, maka agama akan dipersepesikan out of date, mandeg dan terbelakang, Ilmu agama tidak akan bisa berfungsi sesuai dengan jargon shalih likulli zaman wa makan, karena secara prinsip bahwa pemahaman agama tidak mungkin dapat dilakukan dengan sempurna dan murni jika terpisah dari kenyataan hidup manusia.

\section{a. Pengobatan Kuman dengan Kuman}

Ilmu medis modern telah menetapkan sebagian kuman dapat membunuh sebagian kuman yang lain, sebagian ada yang mati dan sebagian ada yang hidup. Seperti pada penyakit cacar dan campak, maka untuk menanggulangi dari penyakit tersebut, maka hewan atau manusia harus diberi racun kuman dari penyakit yang sama. Maksudnya kuman penyakit cacar diambil lalu diletakkan didalam cairan beberapa saat, setelah itu cairan dibersihkan dari kuman, setelah racunnya juga dibuang. Kemudian dinjeksikan ke dalam tubuh manusia, supaya cairan tesebut dapa memangsa kuman penyakit yang ada dalam tubuhnya. Dengan begitu akkhirnya ia tidak akan terjangkit penyakit cacar lagi. Sebagaimana juga ilmu

${ }^{15}$ Ian G. Barbour, When Sciense Meets Religi, terjemahan perjumpaan sains dan agama. (Bandung: Mizan, 2002), h. 42. Bandingkan dengan pandangan John F. Haught, yang membagi pendekatan sains dan agama, menjadi pendekatan konflik, pendekatan kontras, pendekatan kontak, dan pendekatan konfirmasi. 
medis modern telah menetapkan bahwa dalam tubuh babi ada obat untuk menyembuhkan sebagian penyakit, disamping ia juga menetapkan adanya kuman yang mampu mebunuh didalam tubuhnya. Dalam berbagai jenis serangga juga diketahui adanya obat unutk bermacam-macam penyakit. Demikian juga dalam tubuh ular juga diketahui berbagai manfaat. ${ }^{16}$

Ibnu Qutaibah menunjukkan kasus yang serupa, bahwa gigitan ular yang berbisa dapat diatasi dengan mempergunakan daging ular tersebut, dan untuk menyembuh sengatan kalajengking seorang tabib membedah perut kalajengking dan meletakkan pada tempat yang tersengat. ${ }^{17}$ Maka dapat disimpulkan bahwa teori ilmu medis modderna ini telah sesuai dengan hadis Nabi disebutkan bahwa untuk mengobati atau melawan virus dan bakteri pada minuman yang telah dihinggapi lalat, itu dengan cara pengobatan alamiah berupa penetralisiran zat-zat racun yang terdapat pada tubuh lalat sendiri.

Adapun berdasarkan ayat al Quran, metode pengobatan penyakit jasmani meliputi tiga aturan dasar, yakni menjaga kesehatan, mencegah masuknya zat-zat berbahaya ke dalam tubuh dan pembebesan tubuh dari zat-zat yang merugikan. Allah menyebut tiga prinsip dasat ini dalam tiga ayat berbeda, yaitu pada aytat tentang puasa, haji dan bersuci. ${ }^{18}$ Dalam ayat puasa, Allah berfirmana pada QS. Al Baqarah 2: 184. Bahwa Allah mengizinkan orang sakit dan orang dalam perjalanan untuk tidak berpuasa demi menjaga kesehatan dan staminanya selama perjalanan. Dengan tujuan agar kesehatannya tidak terganggu, karena saat itu sedang melakukan aktivitas berat dan membutuhkan asupan gizi untuk

\footnotetext{
${ }^{16}$ Abdullah al Qushaimy, Memahami Hadis-Hadis Musykil, terj. (Pustaka Mantiq, 1993) h. 84

${ }^{17}$ Ibnu Qutaibah, ta'wil Mukhtal al hadis, diterjemahkan oleh Pustaka Azzam dengan judul Hadis-Hadis Yang di Nilai Kontradiktif, (Jakarta: Pustaka Azzam, 2008) h. 386

${ }^{18}$ Ibn Qayyim, ibid, h. 23
} 
menopang energi tubuh. Dalam ayat haji, Allah berfirman pada QS. Al Baqaraḥ2: 196. Bahwa Allah membolehkan orang sakit dan orang yang dikepalanya terdapat sesuatu yang menggangi, sepereti kutu, penyakit kulit dan lainnya untuk mencukur rambutnya yang secara normal terlarang sewaktu melakukan ihram. Dalam hal in, mencukur rambut dan menampakkan kulit kepala dapat menghilangkan zat-zat merugikan yang mengendap dibalik rambut, sehingga penderita dapat membebaskan diri dari penyaliotnya dan puliuh dari kondisi buruk yang disebabkan oleh rambutnya. Adapun tentang cara ketiga berupa tindakan pencegahan, Allah menyebutnya dalam QS. An Nisa 4: 43, bahwa Allah membolehkan orang sakit menggunakan debu yang bersih sebagai ganti air untuk berwudhu. Hal ini dapat menghindarkan tubuh seseorang dari infeksi bila mana ada luka pada bagi tubuh apabila terkena air wudhu

\section{b. Unsur Ilmiah dan Percobaan Laboratorium Pada Sayap Lalat}

Lalat adalah jenis serangga dari ordo Diptera. Perbedaan yang paling jelas antara lalat dan ordo serangga lainnya adalah lalat memiliki sepasang sayap terbang dan sepasang halter, yang berasal dari sayap belakang pada metatoraks (kecuali beberapa spesies lalat yang tidak dapat terbang). ${ }^{19}$ Ia termasuk golongan hewan jenis insekta yang lebih banyak bergerak dengan mempergunakan sayap (terbang), hanya sesekali bergerak dengan kakinya. Beberapa spesies lalat merupakan spesies yang paling berperan dalam masalah kesehatan masyarakat, yaitu sebagai vektor penularan penyakit. Peranan lalat dalam meyebarkan penyakit adalah sebagai vektor mekanik dan vektor biologis. Sebagai vector mekanis lalat membawa bibit-bibit penyakit melalui anggota tubuhnya. Tubuh lalat mempunyai banyak bulu-bulu terutama pada kakinya. Bulu-

\footnotetext{
${ }^{19}$ Wikipedia.com, diakses pada hari Kamis, 9 Juni 2016 , pada jam 08.20
} 
bulu yang terdapat pada kaki mengandung semacam cairan perekat sehingga benda-benda yang kecil mudah melekat. ${ }^{20}$

Dari sisi ilmiah telah diketahui bahwa lalat merupakan serangga buruk yang tersebar di permukaan bumi (kira-kira ada 87.000 macam). Cara membedakannya dapat dilihat dari morfologi yang dimiliki lalat tersebut. Salah satu contoh lalat yang sering kita temukan adalah lalat rumah (Musca domestica). Lalat ini tersebar merata di berbagai daerah. Kebiasaan lalat ini adalah berpindahpindah tempat dari tempat-tempat yang kotor seperti tempat pembuangan sampah, bangkai, bahkan kotoran. Tidak heran apabila pada tubuh lalat ini menempel banyak mikroba dan bakteri yang dapat menyebabkan penyakit. Sedangkan bakteri merupakan benda yang luar biasa kecilnya, ditemukan di berbagai lingkungan bumi dengan jumlah yang diperkirakan mencapai miliaran di setiap gram tanah pertanian, tanpa bakteri tersebut, tanah tidak mungkin bisa ditanami tumbuhan apapun. Oleh karenanya, sebagian besar bakteri juga memiliki manfaat positif, akan tetapi sebagian yang lain dapat menyebabkan penyakit.

Virus adalah zat asam inti atom yang memisahkan diri dari sel-sel hidup tertentu. Namun allah telah memberinya kemampuan mengurus diri sendiri dengan memberi pelindung berupa protein supaya menjadi organisme bebas yang disebut 'unit virus'. Satu unit virus ini mampu menembus sel-sel hidup yang bersinggungan dengannya dan memperosesnya untuk menghasilkan virus baru atau membunuhnya. Oleh karena itu, virus bertanggung jawab atas berbagai macam penyakit yang menyerang tumbuhan, hewan dan

${ }^{20}$ Suraini.Jenis-jenis Lalat (Diptera) dan Bakteri Enterobacteriaceae yang terdapat di Tempat Pembuangan Akhir Sampah (TPA) Kota Padag, dalam di akses pada tanggal 9 Juni 2020 pada website. http://pasca.unand.ac.id/id/wpcontent/uploads/2011/09. 
manusia. Virus yang menyerang sel-sel bakteri di kenal dengan nama virus bakteri atau bacteriphage dan virus yang mematikan bakteri disebut virulent bachteriophage, sedang yang tidak mematikan bakteri ddisebut temperate bachteriophage. ${ }^{21}$

Allah berkuasa menciptakan segala sesuatu di jagad raya ini berpasang-pasangan dan menciptakan materi sekaligus lawannya: psotif-negatif, siang-malam, gelap-terang, sedih-gembira, bahagiasengsara, dan lelaki-perempuan. Ketika lalat jatuh ke dalam sampah, kotoran dan benda-benda kotor yang dipenuhi dengan miliaran bakteri dan virus, Allah telah memberi serangga kecil ini kemampuan membawa kuman pada satu sayapnya dan penawar pada sayap lainnya. Inilah yang dikenal dengan temperate bachteriophage yang membiarkan hidup bakteri yang diserangnya, karena bakteri tersebut memperoleh penangkal yang melawan virus terseebut. Dan jika tidak ada penangkalnya, maka akan punahlah seluruh populasi serangga lalat diakibatkan virus dan bakteri yang menyerangnya. Itulah sebabnya kelestarian serangga hingga saat sekarang mencapai miliaran individu merupakan bukti paling nyata atas kebenaran hadis ini. ${ }^{22}$

Dari segi pengalam empirik, sekelompok peneliti muslim Mesir dan Kerajaan Arab Saudi telah melakukan percobaan terhadap sejumlah gelas yang mengandung air, madu dan beberapa macam jus dalam kadar yang sama antargelas. Gelas-gelas itu dibiarkan terbuka bagi lalat supaya mereka terjatuh ke dalamnya. Pada sebagian gelas, lalat yang jatuh ditenggelamkan dan pada yang lain tidak ditenggelamkan. Hasil uji coba menunjukkan bahwa pada minuman yang tidak ditenggelamkan lalatnta penuh dengan kuman

${ }^{21}$ Najjar, al Ijaz al Ilmy fi As Sunnah An Nabawiyah, h. 280

${ }^{22}$ Najjar, al Ijaz al Ilmy fi As Sunnah An Nabawiyah, h. 281 
dan mikroba, sedangkan pada minuman yang ditenggelamkan lalatnya hampir-hampir bersih dari kuman dan mikroba. ${ }^{23}$

\section{Penutup}

Dalam memahami hadis, integrasi dengan ilmu lain sangat dibutuhkan, khususnya dalam hal sains modern yang mewakili pengkajian kontekstual untuk menambah akurasi kevalidan suatu hadis, karena ciri ajaran Islam adalah tidak bertentangan dengan realitas yang ada. Namun perlu ditekankan bahwa, memang penemuan modern sudah banyak terbukti memiliki keserasian dengan apa yang tertera dalam hadis, tetapi tidak serta merta menyimpulkan bahwa penemuan tersebut sesuai dengan ajaran agama, karena sifat dari penemuan modern itu tidak kekal, sementara kebenaran agama bersifat kekal.

Kemudian memang sebagian besar mikro makhluk hidup seperti kuman, virus dan mikroba yang terdapat dalam tubuh lalat dapat menyebabkan sejumlah penyakit, namun untuk menggagalkan perkembangan mikro makhluk hidup terhadap cairan yang dihinggapinya dengan cara menenggelamkannya. Dan ketika lalat dibiarkan terbang begitu saja maka kemungkinan besar makanan atau minuman terhinggap itu berpotensi menimbulkan penyakit. Teori ini tidak pernah keluar dari para pakar dan pemuka ahli kedokteran, melainkan ia merupakan percikan kemilauannya cahaya kenabian Muhammad. Dengan demikian, maka seorang dokter atau tabib yang arif akan tunduk terhadap sistem kedokteran ini dan akan mengakui bahwa Rasulullah adalah makhluk yang paling sempurna dan dikuatkan oleh wahyu ilahi diluar jangkauan kekuatan manusia".

${ }^{23}$ Najjar, al Ijaz al Ilmy fi As Sunnah An Nabawiyah, h. 282 


\section{Daftar Pustaka}

Zaghlul an Najjar, al Ijaz al Ilmy fi As Sunnah An Nabawiyah, diterjemahkan oleh Zainal Abidin, dkk. Dengan judul Sains Dalam Hadis. Jakarta: Sinar Grafika, 2011.

Muh. Zuhri, Telaah Matan Hadis: Sebuah Tawaran Metodologis, Yogyakarta: Lesfi, 2003.

Suryadi, Metode Penelitian Hadis. Yogyakarta: Teras, 2009.

al Adhlabi, Manhaj an Naqd 'Inda al-Muhadithin terjemahan oleh Ita Qonita dengan judul Menalar Sabda Nabi. Yogyakarta: Insan Madani, 2010.

Abu Rayyah, Adwa' ala as Sunnah an Nabawiyyah. Mesir: Multazam Press, 1985.

Nurun Najwah, Pemahaman Kontekstual Hadis-Hadis Reproduksi Manusia. Yogyakarta: TH Press, 2008.

Ato Muddzhar, Pendekatan Studi Islam dalam Teori dan Praktik, Yogyakarta: Pustaka Pelajar, 2004.

Shalih Fauzan, Tashil al Ilmam bi Fiqh al Ahadis min Bulug al Maram, (Beirut: Dār al-Hadits, 2006.

Yusuf Qardawi, Kaifa Nata'amal maa al Sunnah al Nabawiyah, diterjemahkan oleh Muhammad al Baqir dengan judul Bagaimana memahami Hadis Nabi. Bandung: Kharisma, 1994.

Ibn Qayyim al Jauziyah, at Tibbun al Nabawy, diterjemahkan oleh Abu Firly dengan judul Praktek Kedokteran Nabi. Yogyakarta: Hikam Pustakla, 2010. 
Ibnu Qutaibah, ta'wil Mukhtal al hadis, diterjemahkan oleh Pustaka Azzam dengan judul Hadis-Hadis Yang di Nilai Kontradiktif, Jakarta: Pustaka Azzam, 2008.

Abdullah al Qushaimy, Memahami Hadis-Hadis Musykil, terj. Bandung: Pustaka Mantiq, 1993.

Ian G. Barbour, When Sciense Meets Religi, terjemahan perjumpaan sains dan agama. Bandung: Mizan, 2002.

Suraini. 2011. Jenis-jenis Lalat (Diptera) dan Bakteri Enterobacteriaceae yang terdapat di Tempat Pembuangan Akhir Sampah (TPA) Kota Padag, dalam http://pasca.unand.ac.id/id/wpcontent/uploads/2011/09. Wikipedia.com 